\title{
Urinary cytology in experimental toxic renal injury
}

\author{
A. KENNEDY* AND P. GAIL SALUGA $\dagger$ \\ Departments of Pathology of the Universities of Liverpool and Sheffield
}

\begin{abstract}
Aspirin causes the desquamation of certain epithelial cells and this effect can be demonstrated both in the stomach and, in particular, in the kidney (Harvald, Valdorf-Hansen, and Nielsen, 1960; Harvald and Clausen, 1960; Scott, Denman, and Dorling, 1963; Prescott, 1965, 1966). In the case of the kidney the nephron is lined by a variety of different epithelial cells and it is not clear which of these types of cell is excreted in response to aspirin. In view of the development of analgesic nephritis in a proportion of people who habitually take combinations of analgesics which include aspirin, it is of some interest to localize the site of this desquamative action of aspirin on the kidney. This paper is an account of a morphological study of the cells excreted after giving a series of nephrotoxins of known action to rats. The cells excreted were compared both with their site of origin and with the cells excreted in response to aspirin.
\end{abstract}

\section{Material and methods}

Young adult male rats of the Sprague-Dawley strain were used. During the experiments these were kept in individual stainless steel metabolism cages. They were fed on Diet 41B (Oxoid Ltd.) and fresh water ad libitum. After the collection of baseline specimens of urine, groups of six rats were given the different compounds by the doses and routes shown in the Table. The controls were injected with the solvent alone, i.e. physiological saline, by the appropriate routes. Specimens of urine were collected approximately 24 and $\mathbf{4 8}$ hours after giving the injections. 48 hours after the injections had been given the animals were killed. Previous work has shown that after the administration of nephrotoxins, the increase of cell excretion usually occurs within the first 2 days (Davies and Kennedy, 1967a,b; Davies, Kennedy, and Saluja, 1968; Davies, Kennedy, and Roberts, 1969).

The urine samples were collected over a period of time sufficient to give a volume of 1 to $2 \mathrm{ml}$. of fresh urine. The samples were mixed and films were made using a Shandon Cytocentrifuge running at a speed of 1,500 r.p.m. for 5 minutes. The films were then immediately fixed in absolute alcohol, rehydrated, and stained with haematoxylin and eosin. Specimens containing large
Table Doses and routes used for the administration of the different nephrotoxins

\begin{tabular}{|c|c|c|c|}
\hline Compound is & $\begin{array}{l}\text { Solution used } \\
\text { (mg./ml.) }\end{array}$ & Route & $\begin{array}{l}\text { Dose per } 100 \mathrm{~g} . \\
\text { body weight }\end{array}$ \\
\hline $\begin{array}{l}\text { Mercuric } \\
\text { chloride }\end{array}$ & 1 & Intramuscular & $2 \mathrm{mg}$. \\
\hline $\begin{array}{l}\text { Uranyl } \\
\text { nitrate } \\
\text { dl-serine } \\
\text { Potassium di }\end{array}$ & $\begin{array}{r}30 \\
40\end{array}$ & $\begin{array}{l}\text { Subcutaneous } \\
\text { Intraperitoneal }\end{array}$ & $\begin{array}{l}30 \mathrm{mg} \text {. } \\
80 \mathrm{mg} \text {. }\end{array}$ \\
\hline $\begin{array}{l}\text { chromate } \\
\text { Hexadimethr }\end{array}$ & 10 & Subcutaneous & $4 \mathrm{mg}$. \\
\hline $\begin{array}{l}\text { Hexadimetnr } \\
\text { bromide } \\
\text { Ethyleneimin }\end{array}$ & ine 1 per cent. & $\begin{array}{l}\text { Intramuscular } \\
\text { Intramuscular }\end{array}$ & $\begin{array}{l}4 \mathrm{mg} . \\
0.002 \mathrm{ml} .\end{array}$ \\
\hline $\begin{array}{c}\text { Calcium } \\
\text { aspirin }\end{array}$ & 10 & Gastric tube & $20 \mathrm{mg}$. \\
\hline
\end{tabular}

*"Polybrene" ® Abbott Laboratories. Aldrich Chemical Co. Inc., Milwaukee. Wisconsin.

numbers of cells were diluted as necessary. When the cells were required for staining by histochemical methods, these were carried out immediately after preparation of films by centrifugation.

At necropsy a thin slice of each kidney was fixed in formol-corrosive and dehydrated for the preparation of conventional paraffin sections. In addition, frozen sections of unfixed pieces of kidney were cut for staining by the same histochemical methods applied to the cells. Staining for alkaline phosphatase was carried out using the calcium-cobalt technique and succinic dehydrogenase using nitro BT according to the methods of Pearse (1960). The viability of the cells was tested by assessing their permeability to dilute eosin. Measurements of cells were made with an eyepiece micrometer.

\section{Results}

None of the controls showed any change in the very scanty number of cells they excreted; the rats given the toxins behaved as follows:

\section{MERCURIC CHLORIDE}

The cells excreted in response to mercuric chloride were all large with mean diameters in the order of 


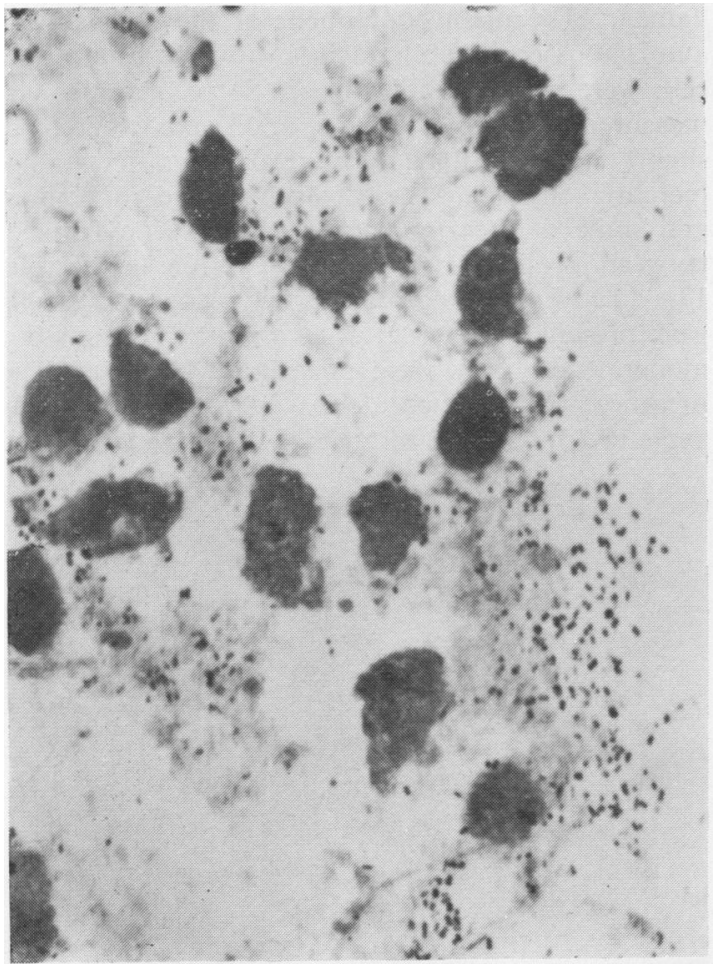

FIG. 1 Cells in urinary sediment after necrosis induced by mercuric chloride. Haematoxylin and eosin. $\times 440$.

$15 \times 10 \mu$. In shape they were oval, pear-shaped, or polygonal and had rather indistinct borders (Fig. 1).

The cytoplasm was granular and brightly eosinophilic and some cells had faintly staining or pyknotic nuclei about $4 \mu$ in diameter. These cells were very similar to the necrotic cells seen in sections of the renal cortex where there was extensive necrosis of the straight segments of the proximal convoluted tubules (Fig. 2). In the urine most of the cells had lost their nuclei and they were permeable to dilute eosin indicating that they were not viable.

URANYL NITRATE

This also causes necrosis of the proximal convoluted tubules (Smith, 1951) and the histological appearances of the kidneys resembled those of the rats given mercuric chloride. In addition, there was some evidence of action on the collecting tubules, the cells of which had basophilic cytoplasm with large nuclei and a number of mitotic figures.

In the urinary sediment (Fig. 3), the main type of cell excreted was large, pear-shaped, and granular. These cells measured $20 \times 12 \mu$ in diameter and in all respects resembled the cells excreted in response to mercuric chloride. In addition, some smaller round or oval cells $12-10 \mu$ in diameter were found; these had a round nucleus and smooth non-granular

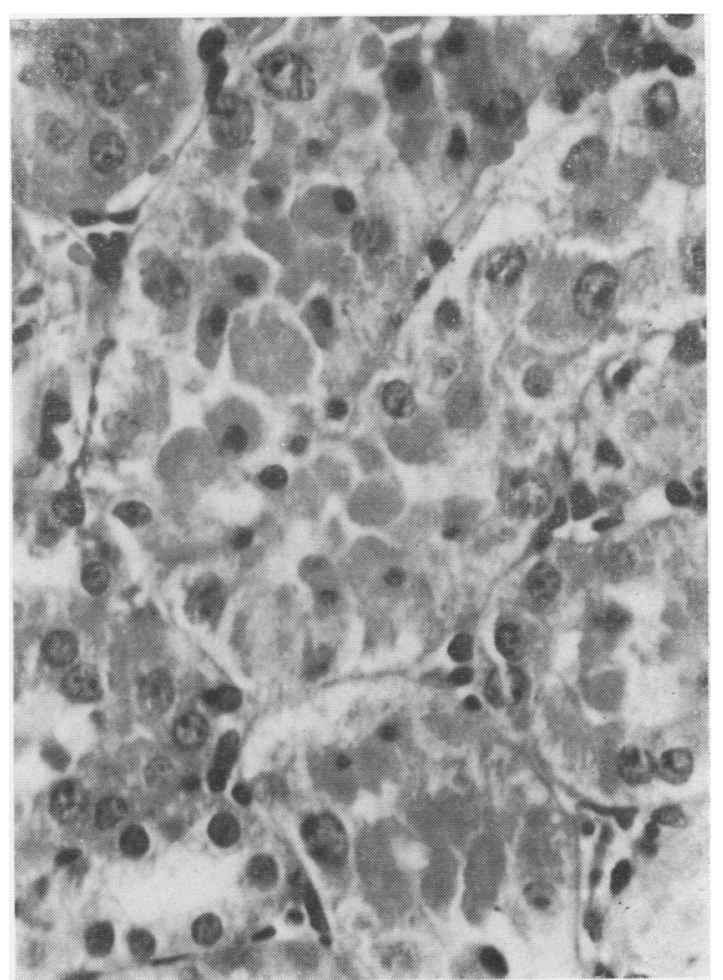

FIG. 2 Renal cortex of a rat 48 hours after mercuric chloride had been given. Haematoxylin and eosin. $\times 440$.

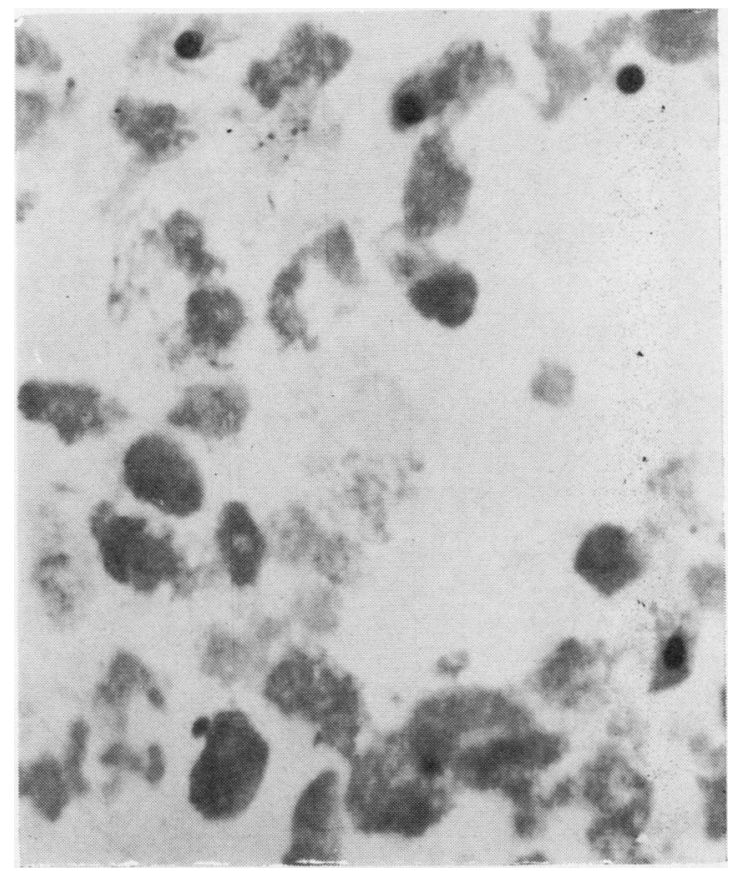

FIG. 3 Urinary sediment after uranyl nitrate had been given. The cells are similar in size and morphology to those in Fig. 1. Haematoxylin and eosin. $\times \mathbf{4 4 0}$. 
cytoplasm. These cells were often present in large clumps and were most frequent on the first day of the experiment. They have some resemblance to the cells excreted by animals given ethyleneimine (vide infra).

\section{DL-SERINE}

The histological changes induced by dl-serine were almost identical with those produced by mercuric chloride. Areas of necrosis occurred in the proximal convoluted tubules in the inner part of the cortex. Large numbers of cells were found in the urinary deposit at both 24 and 48 hours. These cells also were large and had diameters between 15 and $20 \mu$. The cells were oval or rounded with granular eosinophilic cytoplasm and they had a general appearance similar to that of the cells excreted after mercuric chloride had been given. Few cells had nuclei but, like the sediment seen in uranyl nitrate poisoning, small less granular nucleated cells were also present.

\section{POTASSIUM DICHROMATE}

The most notable feature in these animals was the disparity between the small number of intact cells seen in the deposit and the severity of the renal

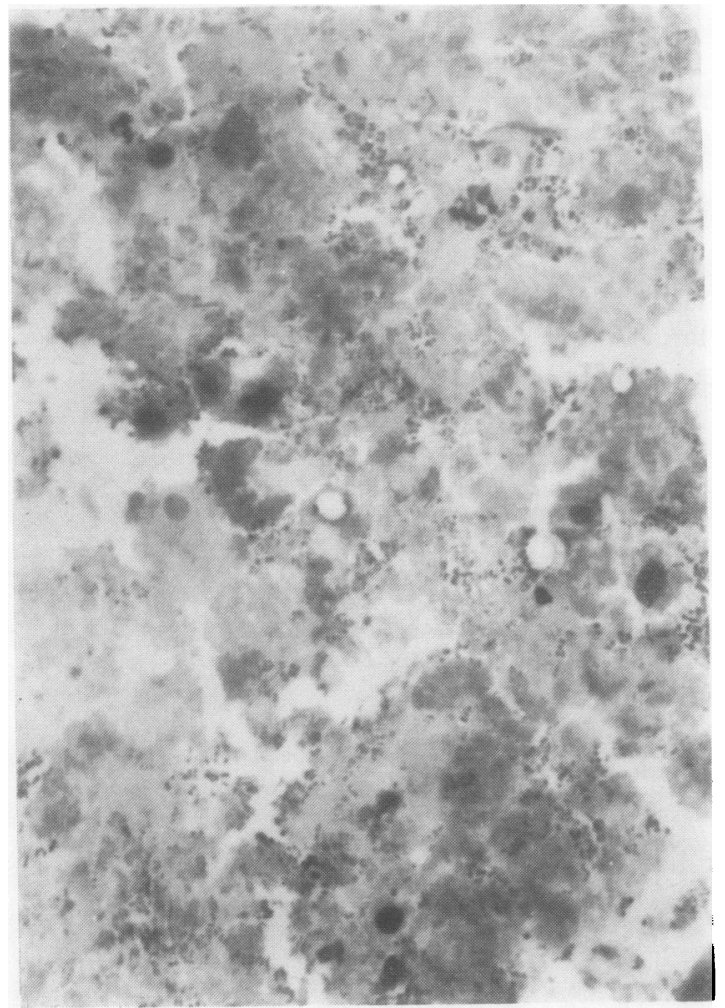

FIG. 4 Few recognizable cells can be seen in the urinary sediment after potassium dichromate had been given; the sediment consists almost entirely of amorphous debris (c.f. Fig. 5). Haematoxylin and eosin. $\times 440$. damage. The main component of the deposit was amorphous eosinophilic debris in which only a few cells were recognizable (Fig. 4). Some of these cells measured about $12 \times 10 \mu$ and were, therefore, slightly smaller than those excreted after giving mercuric chloride. Their margins were ill defined and some of them contained well-preserved nuclei between 5 and $7 \mu$ in diameter. A few larger cells $17 \times 15 \mu$ were also seen. Very few recognizable cells were present 24 hours after giving the injections but moderate numbers were present at 48 hours. The presence of so much debris in the deposit was explained by the appearance of the kidney (Fig. 5).

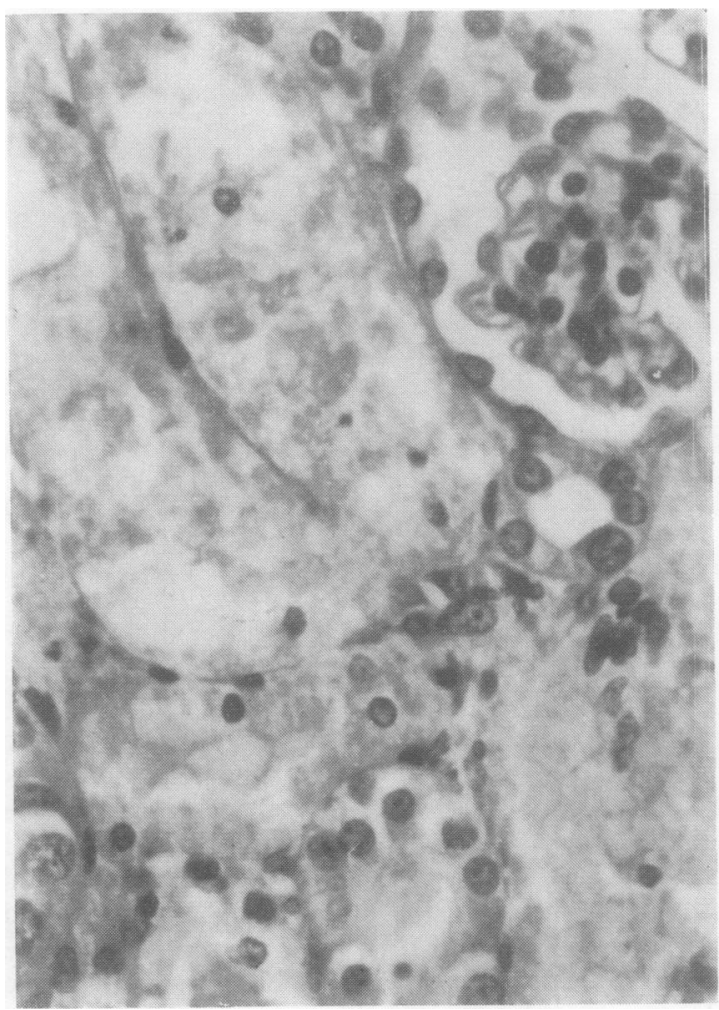

FIG. 5 Renal cortex of a rat which had been injected with potassium dichromate 48 hours previously. There is extensive necrosis of the tubules but the necrotic cells have disintegrated in situ so that the affected tubules contain amorphous debris only. Haematoxylin and eosin. $\times 440$.

In the outer part of the cortex there was necrosis affecting proximal convoluted tubules. In these tubules the cells had disintegrated in situ leaving an amorphous granular deposit similar to that seen in the cytological preparations. This was in complete contrast to the action of mercuric chloride where the necrotic cells remained distinct (Fig. 2).

HEXADIMETHRINE BROMIDE

After this compound had been given the urine con- 


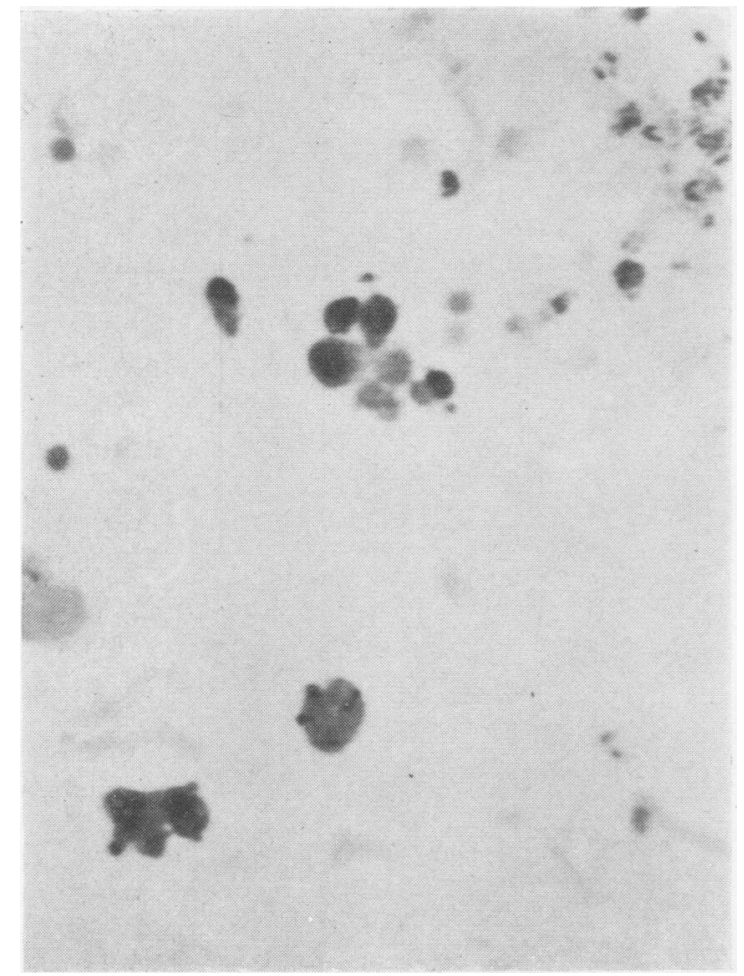

FIG.6 After the administration of hexadimethine bromide, moderate numbers of medium-sized cells with dark round nuclei were found in the urine. Haematoxylin and eosin. $\times 440$.

FIG. 7 Renal cortex of a rat injected with hexadimethrine bromide. A necrotic distal tubule can be seen in the centre of the field; cells resembling those in Fig. 6 are present in this tubule. Haematoxylin and eosin. $\times \mathbf{4 4 0}$.

tained moderate numbers of brightly eosinophilic medium-sized cells, some of which had prominent dark nuclei (Fig. 6). The necrosis induced by hexadimethrine bromide occurs in the ascending limbs of Henle's loops and in the distal convoluted tubules in the cortex. The similarity between the urinary cells and the damaged cells in the renal cortex can be seen by comparing Figs 6 and 7. These cells had an average size of $10 \times 7 \mu$ and were usually oval or pear-shaped with slightly granular cytoplasm.

\section{ETHYLENEIMINE}

This compound causes a highly selective necrosis of the renal papilla (Davies, 1969). The deposit contained well-preserved cells which were characteristically found in clumps or sheets (Fig. 8). The cells had abundant palely-staining cytoplasm and, where they occurred in a sheet, their outlines were angular. Single cells were more rounded and often had a single large vacuole in the cytoplasm; this appearance

FIG. 8 Typical sheet of well-preserved cells in urine of a rat given ethyleneimine. Haematoxylin and eosin. $\times 440$.
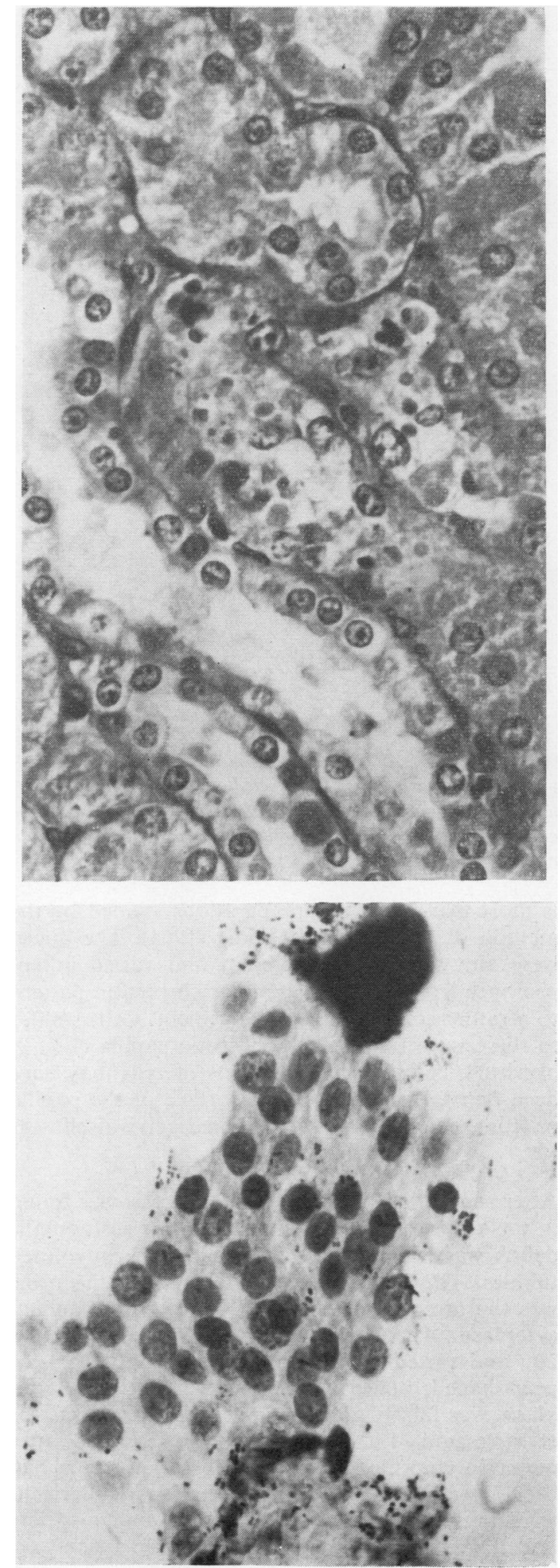


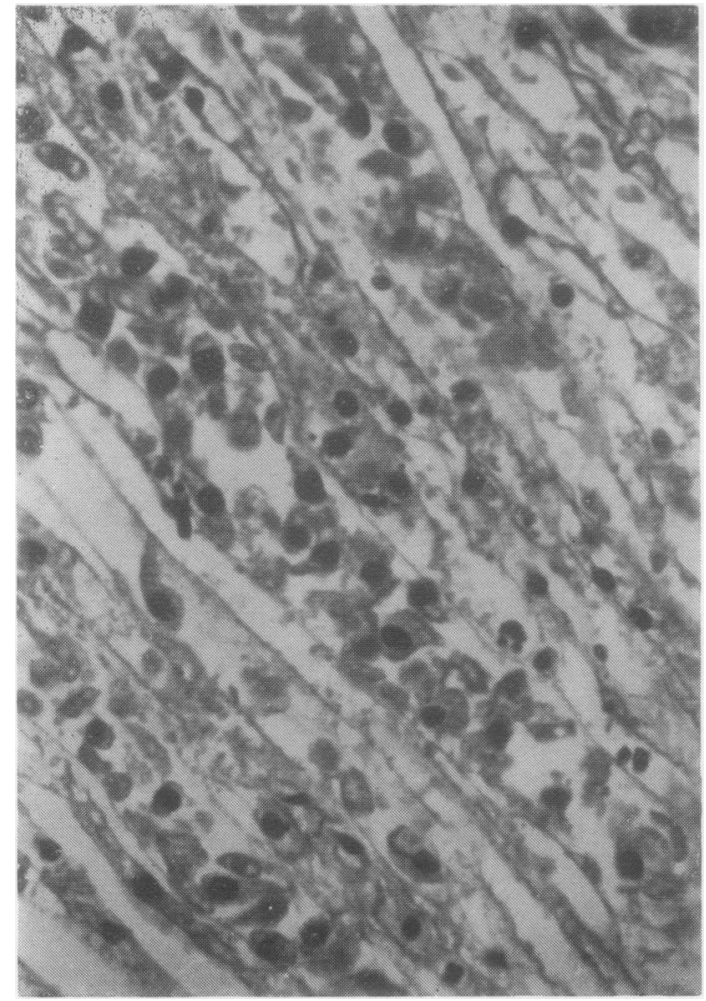

FIG. 9 Necrotic renal papilla from a rat given ethyleneimine. The tubules contain large numbers of cells which have abundant cytoplasm and well-preserved round or oval nuclei. Haematoxylin and eosin. $\times 440$.

is most marked in wet preparations stained by the method of Prescott and Brodie (1964). The nuclei were almost invariably present and varied in appearance from a faintly granular chromatin pattern to a rather coarse lumpy arrangement. Cells similar to these were found in the necrotic papilla (Fig. 9, overleaf), but some of the sheets of cells may have been derived from the pelvic surface of the papilla or from the epithelium of the renal pelvis itself.

\section{CALCIUM ASPIRIN}

After aspirin had been given, no necrosis was found in the kidneys but a certain amount of eosinophilic debris was found in the lumina of the convoluted tubules. The most prominent change in the urine was the presence of large pale cells with abundant cytoplasm. These cells had mean diameters of $15 \mathrm{x}$ $20 \mu$ and varied in form, being oval, polygonal, or pear-shaped; nuclei were usually absent. The cytoplasm was faintly granular and in most respects the cells resembled those which were excreted after mercuric chloride, uranyl nitrate, or dl-serine had been given (Fig. 10). In addition, a few smaller cells were present. These resembled the smaller variety of cell seen after uranyl nitrate had been given.

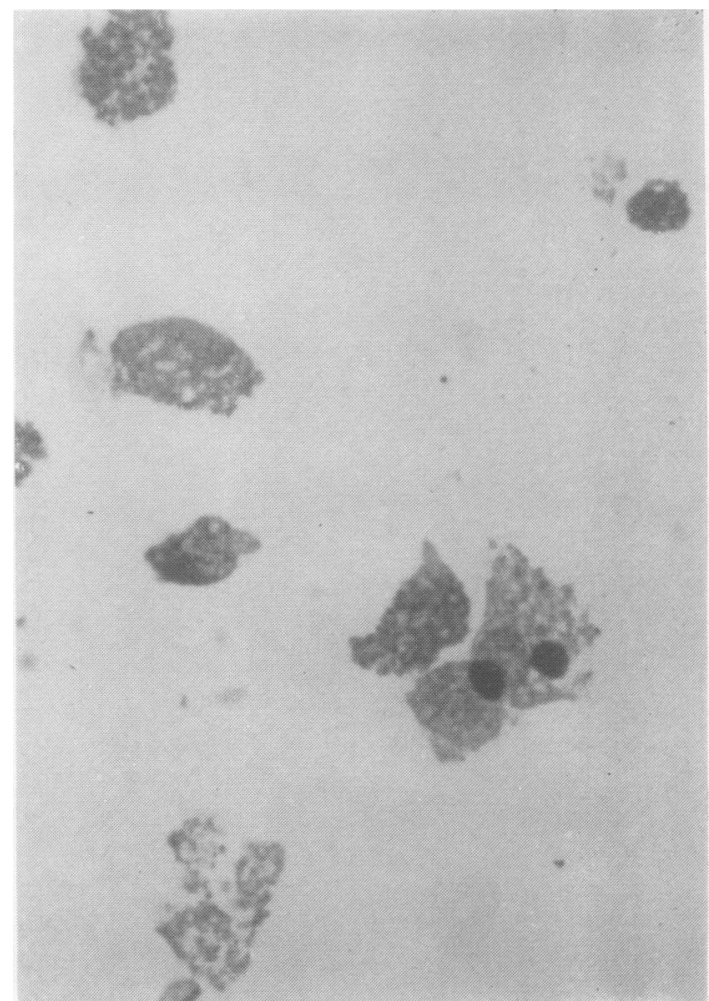

FIG. 10 Typical collection of cells found in urine 48 hours after calcium aspirin had been given by stomach tube. The cells are very similar to those seen in Figs 1 and 3, but a smaller type of cell is present in the top right hand corner. Haematoxylin and eosin. $\times 440$.

\section{Histochemical studies}

Generally these were not as helpful as was hoped, because in most cases it was not possible to identify all of the cells by consistently positive reactions. However, many of the cells excreted after mercuric chloride had been given did contain detectable amounts of alkaline phosphatase activity. Alkaline phosphatase was also detected in some of the cells excreted by the animals given aspirin, indicating that at least some of the cells originated from the proximal convoluted tubules. In all experiments the cells were non-viable as judged by their permeability to dilute aqueous eosin.

\section{Discussion}

These results show that the administration of a number of well-known nephrotoxins is associated with changes in the urinary deposit and that the morphology of the cells excreted depends on the agent given and its site of action. In general, the nephrotoxins which are known to act on the proximal tubule, i.e. mercuric chloride, uranyl nitrate, and dl- 
serine, caused the excretion of large eosinophilic granular cells $15 \mu$ in diameter or greater. Allowing for the mechanical difference in preparing sections and cytological specimens, these cells clearly resembled those seen in the necrotic tubules in the kidney. While it is tempting to conclude that the excretion of cells of this type is a characteristic finding in necrosis of the proximal tubules, it must be pointed out that potassium dichromate, which also acts on the proximal tubule although on a different segment, produced a rather different cytological picture. We have not yet carried out quantitative studies with potassium dichromate, but it appears that relatively few recognizable cells are excreted after the administration of this agent, and the most prominent feature of both the urinary deposit and the histological sections was the presence of eosinophilic debris. This supports the conclusion, drawn previously, that the number of cells excreted after the kidney has been damaged by a toxin depends not only on the degree of damage but also on the site and mode of action of the damaging agent (Davies and others, 1969).

In the case of the two compounds which act more distally, hexadimethrine bromide and ethyleneimine, the cells were smaller and more frequently retained their nuclei. The origins of these cells were also demonstrable histologically but, when ethyleneimine was given, the whole papilla became necrotic so that the cells might have arisen from a variety of sites, including the pelvic epithelium, the ducts of Bellini, and Henle's loops. However, both these toxins caused the excretion of cells which were different from those excreted after giving substances which act only on the proximal convoluted tubules.

Aspirin caused the excretion of large cells which were comparable in size with those excreted after the injection of mercuric chloride, uranyl nitrate, or dl-serine. Their cytoplasm was less granular than that seen after giving the three proximal poisons, but some cells did show alkaline phosphatase activity so that it seems probable that many of the cells excreted in response to aspirin are of proximal origin under the conditions used in this experiment; in the rat very large increases of excretion of proximal cells can occur without irreversible damage to the kidney (Davies and Kennedy, 1967b). While no necrosis was demonstrated in the sections in this experiment, it is relevant that necrosis has been found histologically after large doses of sodium salicylate were given to rats (Robinson, Nichols, and Taitz, 1967) and that the affected part of the nephron was the proximal convoluted tubule. Scott and others (1963) concluded that the 'aspirin cells' originated along a large part of the nephron, including the proximal convoluted tubule, and the unstained cells shown in their Fig. 6 closely resemble the cells we have found after giving mercuric chloride to rats. In our experiments there were also some smaller cells excreted after giving aspirin and these may have had a more distal origin. This is in agreement with the conclusion of Scott and his colleagues that aspirin may have a general irritative effect on a long length of the nephron.

If the main site of action of aspirin is the proximal convoluted tubule, the increase of cell excretion which it produces may not necessarily be relevant to the problem of analgesic nephritis. The primary lesion in analgesic nephritis is probably situated in the medulla, the cortical changes being secondary to the medullary necrosis which eventually occurs(Sanerkin, 1966; Kincaid-Smith, 1967).

\section{Summary}

The cytology of the urinary sediment of rats given different nephrotoxins has been correlated with the histological changes observed in the kidney. Mercuric chloride, uranyl nitrate, and dl-serine all led to the excretion of large eosinophilic granular cells caused by necrosis of the proximal convoluted tubules. The responses to potassium dichromate, hexadimethyrine bromide, and ethyleneimine are described. Aspirin in the dose used did not cause histologically detectable necrosis, but the cells were of at least two types. The most abundant cell was of a type similar to that excreted after the administration of toxins which act on the proximal convoluted tubule. It is concluded that much of the desquamative action of aspirin affects the proximal convoluted tubules, but that other part of the nephron may also be involved.

We wish to thank the Arthritis and Rheumatism Council for the purchase of equipment. Our thanks are also due to Mr. B. Hardman and Mr. T. L. Platts and their respective staffs for their technical help. The photographs are the work of Mrs. M. Row.

\section{References}

DAVIES, D. J. (1969) J. Path., 97, 695 (The structural changes in the kidney and urinary tract caused by ethyleneimine ('vinylamine').

- AND KenNedy, A. (1967a) Brit. J. exp. Path., 48, 45 (Excretion of renal cells following necrosis of the proximal convoluted tubule).

- (1967b) Toxic. appl. Pharmacol., 10, 62 (Course of the renal excretion of cells after necrosis of the proximal convoluted tubule by mercuric chloride). 
, AND Roberts, C. (1969) Brit. J. exp. Path., 50, 319 (The excretion of renal cells following necrosis of the distal segment of the nephron by hexadimethrine bromide).

,-- , ANd Saluja, P. G. (1968) Ann. rheum. Dis., 27, 130 (Significance of the urinary excretion of cells after experimental medullary necrosis).

HaRvald, B., AND Clausen, E. (1960) Lancet, 2, 767 (Nephrotoxicity of acetylsalicylic acid).

-, VAldorf-HANSEN, F., AND NielSEN, E. (1960) Ibid., 1, 303 (Effect on the kidney of drugs containing phenacetin).

KInCAID-Smith, P. (1967) Ibid., 1, 859 (Pathogenesis of the renal lesion associated with the abuse of analgesics).

Pearse, A. G. E. (1960) 'Histochemistry', 2nd ed. Churchill, London.

PrescotT, L. F. (1965) Lancet, 2, 91 (Effects of acetylsalicylic acid, phenacetin, paracetamol, and caffeine on renal tubular epithelium).

(1966) J. Pharm. Pharmacol., 18, 331 (The nephrotoxicity of analgesics).

AND Brodie, D. E. (1964) Lancet, 2, 940 (A simple differential stain for urinary sediment).

Robinson, M. J., Nichols, A., ANd Taitz, L. (1967) Arch. Path., 84, 224 (Nephrotoxic effect of acute sodium salicylate intoxication in the rat).

SANERKIN, N. G. (1966) Brit. J. Urol., 38, 361 (Chronic phenacetin nephropathy).

Scott, J. T., Denman, A. M., AND Dorling, J. (1963) Lancet, 1, 344 (Renal irritation caused by salicylates).

Smith, H. W. (1951) 'The Kidney: Structure and Function in Health and Disease'. Oxford University Press, New York. 